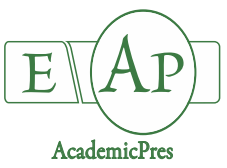

Olaru AL et al. (2020)

Notulae Botanicae Horti Agrobotanici Cluj-Napoca 48(2):681-691

DOI: $10.15835 /$ nbha 48211788

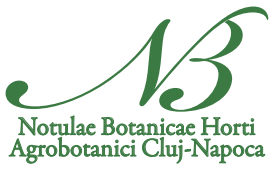

\title{
Evaluation of the cytogenetic effects of Quantis biostimulant in Allium sativum cells
}

\author{
Aurel L. OLARU ${ }^{1}$, Elena ROSCULETE ${ }^{1 *}$, Elena BONCIU ${ }^{1}$, \\ Catalin A. ROSCULETE ${ }^{1}$, Ioan SARAC ${ }^{2 *}$ \\ ${ }^{1}$ University of Craiova, Faculty of Agronomy, 19 Libertatii Street, Craiova, Romania; liviu.olaru.dtas@gmail.com; \\ rosculeta2000@yahoo.com (*correspondingauthor); elena.agro@gmail.com; catalin_rosculete@yahoo.com \\ ${ }^{2}$ Banat's University of Agricultural Science and Veterinary Medicine „King Michael I of Romania”, 119 Calea Aradului Street, \\ Timisoara, Romania; ionutsarac@yahoo.com (*corresponding author)
}

\begin{abstract}
The integration of plant biostimulants use to improve the efficiency of crop production can contribute to increasing the agronomic efficiency. Through this study we aimed to investigate the cytogenetic effects of the Quantis biostimulant on the meristematic cells of Allium sativum (garlic), at different concentrations (1, 1.5 and $2.5 \%$ ) for 8 and $24 \mathrm{~h}$. The results obtained showed that, at 1 and $1.5 \%$ concentration, Quantis induced the increase of the mitotic division intensity in $A$. sativum cells, both during at 8 and $24 \mathrm{~h}$ of treatment, compared to the untreated control variant. This fact suggests that, at the respective concentrations, Quantis improves the growth and development processes of the plant. In contrast, at $2.5 \%$ concentration, the index of mitotic division decreased by $36.6 \%$ (at $8 \mathrm{~h}$ ), respectively by $64.9 \%$ (at $24 \mathrm{~h}$ of treatment), compared to the control. Also, at 2.5\% Quantis, some chromosomal aberrations and nuclear anomalies were recorded: sticky and laggards' chromosomes, C-mitosis, micronucleus, nuclear bud and nuclear dissolution. These results suggest that when is used in high concentrations, Quantis induces some cytotoxic and genotoxic effects on $A$. sativum, which can disrupt the plant growth.
\end{abstract}

Keywords: cytotoxicity; garlic; genotoxicity; mitotic index

\section{Introduction}

The causal links between environmental change and human health are complex because often they are dependent on some modifying factors such as the climate changes and decrease of natural soil fertility. In all economic sectors, the durable development imposes the respect of environment-protection requests (Pandia et al., 2018). In the context of the demographic explosion, producing large amounts of food requires high amounts of fertilizers (Butnariu and Caunii, 2013). Using of chemical fertilizers in agriculture can be very useful for a food production, but on the other hand it may be very dangerous for environment (Zhang et al., 2018). Even that the impact on crop production is obviously profitable, the chemical fertilizers residues are a common cause of soil and water pollution (Pandia $e t$ al., 2012). The Allium test is an often-used short-term 
assay for cytotoxicity testing with various advantages, such as low cost and easy to handle (Liman et al., 2015; Bonciu et al., 2018).

One of the most innovative and promising solutions to address the need to feed the growing world population consists of the use of plant biostimulants. The increased protection of plants against environmental factors after the use of biostimulants, which results in increased productivity and profitability of crop production, represents a potential form of sustainability support in agricultural farms (Hossain and Jahan, 2015; Tarantino et al., 2018; Bulgari et al., 2019; Szparaga et al., 2019). The European market for biostimulants was around 800 million euros in 2018, with an annual growth potential of more than 10\% (Saporta et al., 2019).

A large type of biomass can serve as sources of biostimulants. This biomass includes any type of regenerable organic material, comprising the agricultural plants, forest species or perennials, humic substances, microalgae, etc. as well as ensemble of wastes and organic residues from agriculture (Samfira et al., 2013). Enzymes, proteins, amino acids, micronutrients, and other compounds may be used as biostimulants (du Jardin, 2015). Due to diversity of source materials, the mode of action of biostimulants is not easily determined. The development of any new products for plant growth should proceed on the basis of a systemic approach founded in chemical synthesis and biochemistry (Butnariu, 2012; Bostan et al., 2013).

Quantis is a biostimulant produced by SAF Argentina S.A., Buenos Aires and distributed in Romania by Syngenta Agro SRL Bucuresti. Quantis is an amino acid-based product, derived from a natural fermentation process of yeast production which contains organic carbon (13.56\%), potassium (8.84\%), calcium (1\%) and amino acids to mitigate drought and heat stress. Also, it contains osmoprotectants (substances that aid in water balance under conditions of water scarcity, favouring plants growth) and antioxidant substances which delay senescence will help to achieve productive potential. The liquid formula of the Quantis product is suitable for application in diluted solutions at a concentration of $1 \%$. The best time to apply Quantis is before or during the essential physiological phases of the plants, such as flowering.

The use of biostimulants and biofertilizers begins with the intent of stimulate plant growth or increase yield but excessive application may have the opposite effect (Lyszkowska et al., 2008). Therefore, we aimed in this study to evaluate the cytogenetic effects of Quantis biostimulant, starting from the doses recommended by the producer (1\%) but it was also tested higher concentrations, based on the idea that some farmers may overuse it. Since in Romania organic farming is still in the pioneering stage, in order to increase productivity, farmers frequently use higher doses of fertilizers than those recommended by producers. It was chosen this product because the information provided by the manufacturer on the product label (origin, composition) is insufficient.

\section{Materials and Methods}

\section{Biological material and microscopic preparations}

In this study, bulbs of $A$. sativum ( $2 n=16$ ), purchased from local market of Craiova (Romania), were used as the test system. Quantis biostimulant was purchased from Syngenta Agro SRL Romania and was used as the test substance. Although Quantis is a foliar product, in order to highlight the cytological activity and the occurrence of some cytogenetic abnormalities, it must be tested on meristematic roots. For this reason, it was chosen Allium test because is one of the simplest, inexpensive and valuable tests for determining the cytotoxicity of chemical substances on plants.

The garlic bulbs were immersed in glasses with tap water for $72 \mathrm{~h}$, time required for the roots occurrence. When the roots reached the length of $10-15 \mathrm{~mm}$, they were immersed in dilutions of different concentrations of Quantis $(1,1.5$ and $2.5 \%)$ for 8 and $24 \mathrm{~h}$. The experiment was performed in laboratory, at room temperature $\left(24 \pm 2{ }^{\circ} \mathrm{C}\right)$. Solutions were diluted with distilled water; the distilled water being used for the control variant too. Ten bulbs of $A$. sativum were used for each treatment variant as well as an untreated control. The $A$. 
sativum roots were fixed in ethanol:acetic acid (3:1) and hydrolysed in $1 \mathrm{~N}$ hydrochloric acid $(\mathrm{HCl})$ at $60^{\circ} \mathrm{C}$ for $5 \mathrm{~min}$. The roots then were transferred on clean slide and stained by crushed in drop of $2 \%$ acetocarmine.

The microscopic preparations were performed by squash technique. For this purpose, the slide was placed and coverslip on a double layer of paper towel, then paper was folded over the coverslip and squash down on the coverslip with a strong vertical pressure, using thumb. The pressure was applied to squash the root tip into a single cell layer.

The microscopic slides were examined at $1000 \times$ magnification. Minimum 1000 cells were counted for each slide and each concentration and time. For each treatment there were 10 meristematic roots used. Then, the number of cells in the mitosis divisions was scored and the mitotic index (MI) was determined. Each phase of mitosis division was also observed.

\section{Statistical analysis}

The viewing microscopic area was divided into three viewing sections and then, in each viewing section, the cells were counted and recorded in prophase, metaphase, anaphase and telophase. The mitotic index (MI) and mitosis phase index (IP = prophase index; IM = metaphase index; IA = anaphase index; IT = telophase index) were calculated using the following formulas:

$$
\begin{aligned}
& \text { MI }(\%)=\frac{\text { Total number of cells in division }}{\text { Total number of analysed cells }} \times 100 \\
& \text { IP }(\%)=\frac{\text { Total number of cells in prophase }}{\text { Total number of cells in mitosis }} \times 100 \\
& \text { IM }(\%)=\frac{\text { Total number of cells in metaphase }}{\text { Total number of cells in mitosis }} \times 100 \\
& \text { IA }(\%)=\frac{\text { Total number of cells in anaphase }}{\text { Total number of cells in mitosis }} \times 100 \\
& \text { IT }(\%)=\frac{\text { Total number of cells in telophase }}{\text { Total number of cells in mitosis }} \times 100
\end{aligned}
$$

The index of the total abnormalities (ITA) was also calculated:

ITA $(\%)=\frac{\text { Total number of aberrant cells }}{\text { Total number of cells in division }} \times 100$

Chromosomal aberrations and nuclear anomalies were determined by scoring cells with sticky and laggards' chromosomes, C-mitosis, micronucleus, nuclear bud and nuclear dissolution in randomly picked three zones per slide. For each concentration and control, the mean values were calculated. The analysis of variance (ANOVA) was used to assess the significant differences between the control variant and each treatment. The differences between treatment means were compared using the LSD-test at a probability level of $0.05 \%$ subsequent to the ANOVA analysis.

Photomicrographs of cells showing mitosis, chromosomal aberrations and nuclear anomalies were taken using the Kruss microscope (produced by Kruss Optronic, Hamburg, Germany).

\section{Results}

\section{Mitotic index and mitosis phases index}

Evaluation of cytogenetic effects of Quantis on meristematic cells of $A$. sativum was estimated by observing cytological parameters, i.e. the mitotic index and index of the different stages of mitosis (Table 1).

At the 1.0 and $1.5 \%$ concentration of Quantis and $8 \mathrm{~h}$ exposure time, MI recorded higher values than the control, namely 15.6 respectively $13.3 \%$, which means an increase by $54.4 \%$ respectively $31.6 \%$. The same was observed in the case of increasing the exposure time to $24 \mathrm{~h}$ but with maintaining the concentrations of 1 and $1.5 \%$ Quantis, when the MI values were 14.4 respectively $12.0 \%$. This means an intensification of mitotic activity by 23 respectively $2.5 \%$ compared to the control variant. These values suggest the positive effect of Quantis on the growth and development of the plant, especially at a concentration of maximum $1 \%$. 
On the other hand, at the concentration of 2.5\%, Quantis induced a strong mitodepressive effect in meristematic cells of $A$. sativum, this effect being expressed by the significant reduction of MI at both 8 and 24 $\mathrm{h}$ exposure time, resulting significantly differences from control $(\mathrm{p}<0.05)$. Thus, at $8 \mathrm{~h}$ exposure time, MI recorded a value of $6.4 \%$, that is a decrease of $36.6 \%$ compared to the control, while at $24 \mathrm{~h}$ exposure time, the mitodepressive effect was even more pronounced, the value of MI being only $4.1 \%$, i.e. a dramatic reduction of mitotic activity, by $64.9 \%$ compared to the control.

Table 1. Mitotic index and mitotic phase index of $A$. sativum root tip cells exposed to different concentrations of Quantis (mean \pm SD)

\begin{tabular}{|c|c|c|c|c|c|c|}
\hline \multirow{2}{*}{ Time $(\mathrm{h})$} & Concentration $(\%)$ & $\begin{array}{c}\text { MI } \pm \text { SD } \\
(\%)\end{array}$ & $\begin{array}{c}\text { IP } \pm \text { SD } \\
(\%)\end{array}$ & $\begin{array}{c}\text { IM } \pm \text { SD } \\
(\%)\end{array}$ & $\begin{array}{c}\text { IA } \pm \text { SD } \\
(\%)\end{array}$ & $\begin{array}{c}\text { IT } \pm \text { SD } \\
(\%)\end{array}$ \\
\hline \multirow{3}{*}{8} & Control (untreated) & $10.1 \pm 1.4$ & $57.5 \pm 3.4$ & $17.8 \pm 3.2$ & $10.3 \pm 1.8$ & $14.4 \pm 2.6$ \\
\cline { 2 - 7 } & 1.0 & $15.6 \pm 2.0$ & $59.7 \pm 3.4$ & $16.5 \pm 3.4$ & $9.8 \pm 2.9$ & $14.0 \pm 2.0$ \\
\cline { 2 - 7 } & 1.5 & $13.3 \pm 1.8$ & $66.2 \pm 3.7$ & $11.4 \pm 3.2$ & $9.1 \pm 2.4$ & $13.3 \pm 2.4$ \\
\cline { 2 - 7 } & 2.5 & $6.4 \pm 0.4^{*}$ & $72.4 \pm 4.7$ & $10.5 \pm 3.1$ & $7.4 \pm 3.3$ & $9.7 \pm 3.2$ \\
\hline \multirow{3}{*}{24} & Control (untreated) & $11.7 \pm 1.5$ & $56.4 \pm 2.9$ & $18.4 \pm 3.3$ & $11.1 \pm 3.3$ & $14.1 \pm 2.6$ \\
\cline { 2 - 7 } & 1.0 & $14.4 \pm 2.9$ & $58.9 \pm 3.4$ & $16.1 \pm 3.4$ & $10.2 \pm 2.0$ & $14.8 \pm 2.5$ \\
\cline { 2 - 7 } & 1.5 & $12.0 \pm 2.5$ & $64.8 \pm 3.5$ & $14.9 \pm 2.9$ & $9.5 \pm 2.8$ & $10.8 \pm 1.9$ \\
\cline { 2 - 7 } & 2.5 & $4.1 \pm 0.5^{*}$ & $86.4 \pm 4.6$ & $7.3 \pm 3.9$ & $4.1 \pm 3.0$ & $2.2 \pm 3.4$ \\
\hline
\end{tabular}

Note: $\mathrm{MI}=$ mitotic index; $\mathrm{SD}=$ standard deviation; IP = prophase index; IM = metaphase index; IA = anaphase index; IT = telophase index.

*statistically significant at $\mathrm{p}<0.05$ when compared with untreated control.

\section{Cytological abnormalities}

The exposure to different concentrations of Quantis caused irregularities of dividing cell cycles to $A$. sativum. Thus, the increase of the percentage of prophase was accompanied by a decrease in metaphase and anaphase percentage in all treatments and both exposure periods. The obtained results show that as the concentration of Quantis and the exposure time increases, the frequency of chromosomal and nuclear abnormalities increases as the MI is inhibited.

A low percentage of chromosomal and nuclear abnormalities confirms that at a $1 \%$ and $1.5 \%$ concentration and an $8 \mathrm{~h}$ exposure time, Quantis does not have a genotoxic effect on the meristematic cells of garlic. On the other hand, at a $2.5 \%$ concentration, Quantis induced, at both time periods of exposure, the appearance of some chromosomal aberrations and nuclear anomalies (Figure 1 and Table 2). The most frequently identified abnormalities were sticky chromosomes (Figure 2A), laggards' chromosomes (Figure 2B; 2C; 2D), micronucleus (Figure 2E; 2F; 2G(a)), C-mitosis (Figure 2H), but nuclear bud (Figure 2G(b)) and nuclear dissolution (Figure 2I) were also observed.

Table 2. Type and frequency of chromosomal aberrations and nuclear anomalies in $A$. sativum meristematic cells after exposure to Quantis (mean \pm SD)

\begin{tabular}{|c|c|c|c|c|c|c|c|}
\hline \multirow{2}{*}{ Time (h) } & Concentration (\%) & $\begin{array}{c}\mathrm{S} \pm \mathrm{SD} \\
(\%)\end{array}$ & $\begin{array}{c}\mathrm{L} \pm \mathrm{SD} \\
(\%)\end{array}$ & $\begin{array}{c}\mathrm{CM} \pm \mathrm{SD} \\
(\%)\end{array}$ & $\begin{array}{c}\mathrm{MN} \pm \mathrm{SD} \\
(\%)\end{array}$ & $\begin{array}{c}\mathrm{NB} \pm \mathrm{SD} \\
(\%)\end{array}$ & $\begin{array}{c}\mathrm{ND} \pm \mathrm{SD} \\
(\%)\end{array}$ \\
\hline \multirow{4}{*}{8} & Control (untreated) & $0.0 \pm 0.0$ & $0.0 \pm 0.0$ & $0.0 \pm 0.0$ & $0.0 \pm 0.0$ & $0.0 \pm 0.0$ & $0.0 \pm 0.0$ \\
\cline { 2 - 8 } & 1.0 & $0.4 \pm 1.0$ & $0.3 \pm 0.9$ & $0.3 \pm 0.8$ & $0.0 \pm 0.0$ & $0.1 \pm 0.8$ & $0.0 \pm 0.0$ \\
\cline { 2 - 8 } & 1.5 & $0.7 \pm 0.8$ & $0.8 \pm 1.4$ & $0.4 \pm 1.4$ & $0.3 \pm 0.9$ & $0.1 \pm 0.7$ & $0.0 \pm 0.0$ \\
\cline { 2 - 8 } & 2.5 & $7.0 \pm 3.0$ & $5.0 \pm 3.1$ & $3.0 \pm 2.1$ & $4.1 \pm 2.6$ & $2.3 \pm 1.3$ & $2.1 \pm 1.3$ \\
\hline \multirow{3}{*}{24} & Control (untreated) & $0.0 \pm 0.0$ & $0.0 \pm 0.0$ & $0.0 \pm 0.0$ & $0.0 \pm 0.0$ & $0.0 \pm 0.0$ & $0.0 \pm 0.0$ \\
\cline { 2 - 8 } & 1.0 & $0.8 \pm 1.1$ & $0.6 \pm 0.9$ & $0.4 \pm 1.1$ & $0.4 \pm 1.2$ & $0.2 \pm 0.5$ & $0.1 \pm 0.4$ \\
\cline { 2 - 8 } & 1.5 & $0.9 \pm 1.4$ & $0.7 \pm 1.0$ & $0.5 \pm 1.7$ & $0.3 \pm 1.0$ & $0.2 \pm 0.4$ & $0.2 \pm 0.3$ \\
\cline { 2 - 8 } & 2.5 & $8.0 \pm 3.4$ & $6.0 \pm 2.9$ & $5.0 \pm 3.2$ & $4.0 \pm 3.6$ & $3.0 \pm 1.0$ & $2.4 \pm 1.4$ \\
\hline
\end{tabular}

Note: $\mathrm{S}$ = sticky chromosomes; $\mathrm{L}$ = laggards chromosomes; $\mathrm{CM}=\mathrm{C}$-mitosis; $\mathrm{MN}$ = micronucleus; $\mathrm{NB}$ = nuclear bud; $\mathrm{ND}=$ nuclear dissolution; $\mathrm{SD}=$ standard deviation. 


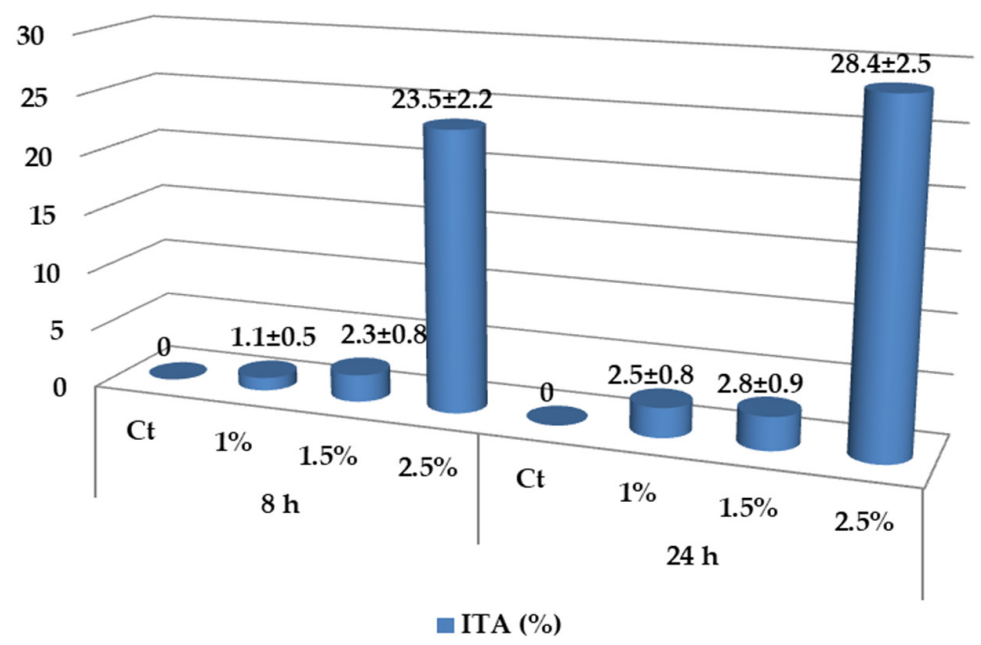

Figure 1. The index of total abnormalities (ITA \pm SD - standard deviation) for A. sativum meristematic cells after an $8 \mathrm{~h}$ long and $24 \mathrm{~h}$ long exposure to Quantis (1\%, 1.5\% and $2.5 \%$ concentration)

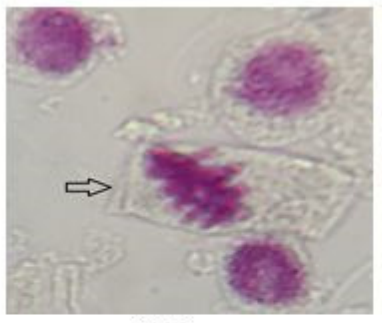

(A)

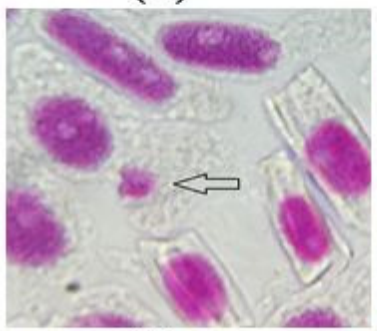

(E)

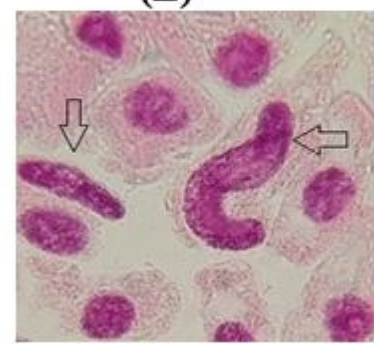

(I)

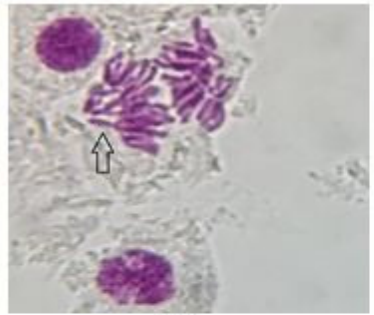

(B)

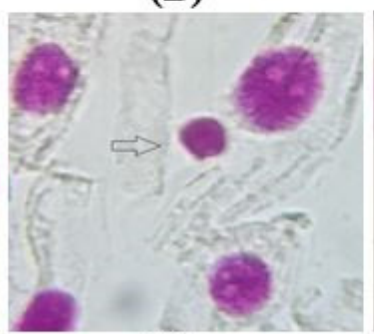

(F)

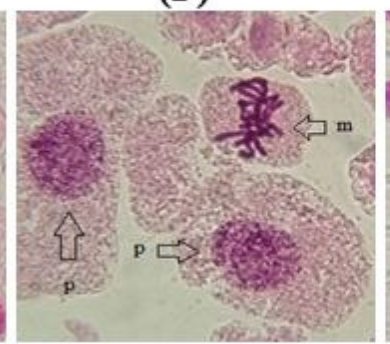

(J)

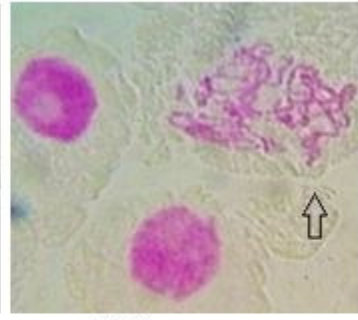

(C)

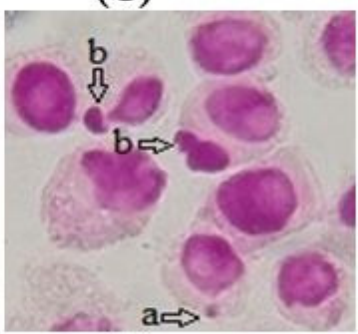

(G)

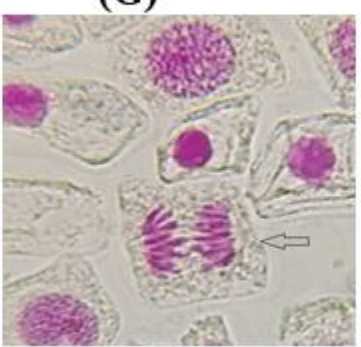

(K)

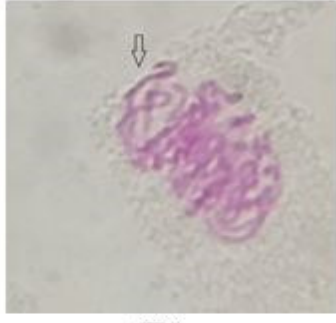

(D)

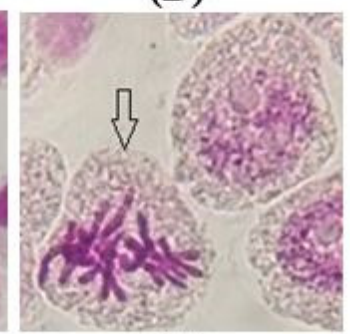

(H)

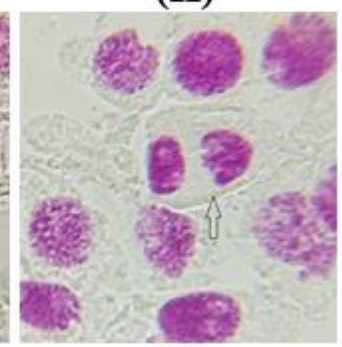

(L)

Figure 2. Cytogenetic effects induced by Quantis in meristematic cells of A. sativum (1000x magnification): sticky metaphase (A); disturbed anaphase with laggards chromosomes (B); disturbed metaphase with laggards chromosomes (C,D); micronucleus (E,F,G(a)); nuclear bud (G(b)); C-mitosis $(\mathrm{H})$; nuclear dissolution $(\mathrm{I})$; normal mitosis in untreated cells (control): prophase $(\mathrm{p})$ and metaphase $(\mathrm{m})$ $(\mathrm{J})$; anaphase $(\mathrm{K})$ and telophase $(\mathrm{L})$ 


\section{Discussion}

In agricultural soil, fertilizer application potentially influences soil nutrients, their availability properties and crop yield, but some chemical products used in agriculture for plant protection and growth can lead to harmful effects on human and environmental health (Liu et al., 2010). In recent years more attention has been paid to the organic agriculture which excludes the synthetic compounds. Organic agriculture is a system of production which combines the most beneficial practices for the environment (Georgieva et al., 2016). While biostimulants and eco-friendly fertilizers hold promise for more environmentally protection, they have to be optimized further to make them useable on large scales. For plant growing it is necessary not only the availability of certain nutrients, but these nutrients should be at an appropriate rate and applied in the respective phase of plant development (Osuna et al., 2015). The justification of biostimulant claims should be done for the minimum recommended dose necessary to achieve the desired effect.

As Tarantino et al. (2018) suggests, the effects of the biostimulants activities vary depending on the type of biostimulant used and the plant variety. However, it should be noted that most of them has several benefits over traditional fertilizers (Hossain and Jahan, 2015). For instance, humic acids stimulate the growth of the root system of the plants and represent an excellent fertilizer in the modern trends such as sustainable agriculture and organic farming (Vasileva, 2015). On the other hand, some of the cons of the eco-friendly fertilizers include negative impacts to the environment including increased emissions of gases during production; additionally, they are expensive, which currently limits their use to specialty crops (Chen et al., 2018). There are some studies regarding the negative effects of biostimulants on the growth of the plants. For example, foliar and root application of a product containing amino acids from animal origin have been reported to cause severe plant-growth depression and negative effects on Fe nutrition (Cerdan et al., 2013).

In our study, different parameters of $A$. sativum such as mitotic index, chromosomal aberrations and nuclear anomalies were used to estimate the cytotoxicity and genotoxicity of fertilizer Quantis. MI can be used as a parameter in evaluating cell division frequency. The cytotoxicity level can be determined by the decreased rate of MI (Rosculete et al., 2019). The inhibition of MI, induction of chromosomal aberration and nuclear anomalies in Allium species have been considered as indicators of citotoxicity (Yüzbaşioğlu et al., 2003; Bonciu et al., 2018). The Allium test provides a rapid screening procedure for different pollutants which may represent environmental hazards (Leme and Marin-Morales, 2009; Rosculete et al., 2019). The garlic is easy to grow and doesn't require any sterile conditions so it is easy to observe chromosomal aberrations and nuclear abnormalities with this system.

There are few studies in the literature on the cytotoxic and genotoxic effects of biostimulants or ecofriendly fertilizers on plants. However, there are some results about negative effects induced by biostimulants, which could be due to incorrect product concentration. For example, the results obtained by Ruiz et al. (2000) indicated that the application of certain biostimulants, such as fosfonutren, can cause a negative effect on the efficiency and utilization of NO3, resulting in a drastic loss in growth and yield of pepper (Capsicum annuum L.), even under the control treatment, in which no biostimulants was applied. Also, foliar and root applications of the biostimulants which contain amino acids caused severe plant growth depression and nonpositive effects to tomato plants (Cerdán et al., 2009).

Ricci et al. (2019) stated that for demonstrating that a product is indeed a bona fide biostimulant depends on a demonstration of its effect and this should not be confused with guaranteeing a specific level of efficacy. Under no circumstances should the placing of a biostimulant on the market be considered to guarantee effectiveness under all conditions, as many factors may influence performance of a biostimulant in the field. Unlike fertilizers, knowing the ingredients of a biostimulant is not enough to understand how it will affect crop. Biostimulants are defined more by what they do, than by what they are.

The results obtained in our study suggest that Quantis have a positive effect of on the growth and development of the plant but especially in the $1 \%$ concentration. Use of Quantis in high concentrations and 
high exposure time caused a significant decrease of the MI in A. sativum meristematic cells. These results are also confirmed by other authors, who have shown that in some situations such as application in excess, biostimulants might induce no-response or negative responses in agricultural plants: peppers (Csizinszky, 1990), cabbage (Heckman, 1995), hazelnut trees (Kelting et al., 1997), strawberries (Neri et al., 2002; Prokkola and Kivijärvi Parikka, 2003; Lisiecka et al., 2011), lettuce (Lyszkowska et al., 2008), tomato (Gajc-Wolska et al., 2009), maize (Asli and Neumann, 2010), okra (Kirn et al., 2010), etc.

MI lower than control may be derived from the development of exposed organisms having been affected by test compounds. Some authors consider that the reduction of MI may be due to the mito-depressive action of tested substances, which interfere in the normal cell cycle resulting in decrease in number of dividing cells (Sharma and Vig, 2012). Also, the inhibition of MI it may be due to inhibition of DNA synthesis or blocking of G1 phase, suppressing DNA synthesis or effect of test compound at G2 phase of the cell cycle (Özkara et al., 2015).

The highest mitodepressive effect and significant mitotic damage of Quantis in the A. sativum root tip cells were detected at $2.5 \%$ concentration and $24 \mathrm{~h}$ exposure time. The decrease in the mitotic index was found to be strongly concentration-dependent, as were the increase of the chromosomal aberrations and nuclear abnormalities. Likewise, Ali et al. (2019) reported that the $A$. cepa roots treated with a biostimulant based to bread yeast extract shows a concentration-dependent reduction of mitotic index values, as well as the appearance of several types of cytological abnormalities: sticky chromosomes, micronucleus, bridges, disturbed prophase, disturbed anaphase, etc. These findings suggest that $A$. sativum assay can be successfully employed for environmental risk assessment of the Quantis biostimulant.

In our study, the increase of the percentage of prophase was accompanied by a decrease in metaphase and anaphase percentage in all treatments and both exposure periods. According to Abu, Ngozi and Ezeugwu (2008), prophase accumulation probably resulted in a reduction in the number of cells that progressed mitotically to other phases.

The treatment with $2.5 \%$ concentration of Quantis increased the percentage of chromosome aberrations in observed dividing cells. One of the most frequently identified abnormalities was sticky chromosomes. Many authors consider that stickiness is a common sign of toxic effects of different pollutants on chromosomes, usually of an irreversible type and probably who leading to cell death (Khanna and Sharma, 2013; Kaushik et al., 2017). Also, Kara et al. (1994), appreciate that the abnormalities such as stickiness, multipolar anaphase, and unequal chromosome distributions can affect the vigour, fertility, yield or competitive ability of the exposed plants. The appearance of sticky chromosomes indicates that the pollutant may affect the organization of the chromatin.

Other aberrations, such as laggards' chromosomes, C-mitosis and micronucleus were also observed in our experiment. In an experience with neem leafs extract, some authors concluded that the observation of laggard's chromosomes at anaphase is an indication of the capability of neem in causing chromosome breakage to Allium cepa, resulting in genetic imbalance in the genome (Adegbite et al., 2009). C-mitosis is an aberration induced in the cells by genotoxic substances and the result is damaged mitotic apparatus (Firbas and Amon, 2014). The appearance of C-mitosis and micronucleus formations in meristematic cells of $A$. sativum exposed to $2.5 \%$ Quantis indicates the potential for genotoxicity of this fertilizer when it is applied in higher concentrations than those recommended by the manufacturer.

One of the nuclear anomalies identified in meristematic cells of garlic exposed to high concentrations of Quantis was the nuclear dissolution. Some authors consider that the apperance of nuclear dissolution gives cytological evidence for the inhibitory action on DNA biosynthesis during $S$ phase of mitotic cell cycle (Akaneme and Iyioke, 2008; Firbas and Amon, 2014). In this context, the results of our study suggest that at $2.5 \%$ concentration, Quantis can have an inhibitory effect on DNA biosynthesis in A. sativum root tip cells.

In spite of the supposed low toxicity of the biological and organic products, an evaluation system to assess its possible damage to humans and environment must be used (Valiente et al., 2013). The biostimulant 
Quantis has not been tested on animal systems; instead, there are results of other researches carried out with other biological products. Thus, Gluticid, an biological fungicide, was found to be a causative agent of genotoxic and citotoxic effects in somatic cells of female mice at the tested doses (Valiente et al., 2013).

Although many companies invest in the development of new biostimulant products, their compounds are mostly poorly characterized or sometimes even unknown and impossible to characterize (Bulgari et al., 2019); in case of the Quantis biostimulant, it is marketed in Romania without field efficiency data. This was the reason to test the cytological effects of this product based on the Allium test, one of the simplest, fastest and cheapest tests. While some biostimulants have been analysed with regard to unwanted side effects including negative impact on the natural environment, most biostimulants have not been fully characterized; in fact, in many countries biostimulants are not subject to rigorous toxicological screening (Janas and Posmyk, 2013). That's why the complexity of biostimulants products requires the application of novel biochemical, genetic and statistical approaches. Due to the fact that some synthetic biostimulants are mixtures of potentially toxic compounds, scientific research should indicate a specific range of concentrations for working solutions that can be used by farmers in practice. This will enable sustainable crop management with minimal impact on the natural environment (Szparaga et al., 2019).

\section{Conclusions}

Research results show that the cytotoxicity of Quantis on A. sativum roots cell depends on the concentrations and times. Based on results obtained in this study it could be recommended that the farmers continue to use Quantis, but compliance with the concentrations imposed by the manufacturer is a mandatory condition to obtain the expected results but also to not affect the environment health. Farmers must keep in mind that a biostimulant does not require its excessive application, because the effects on the plants and environment can be negative. Without limiting the environmental pollutants, it is highly unlikely to preserve the sustainable development goals. Future testing of other eco-friendly products used in agriculture (biostimulants, fertilizers or pesticides) is intended, in terms of overuse and possible cytotoxic and genotoxic effects in meristematic cells of different tested plants and their potential to affect the plant growth.

\section{Acknowledgements}

This research received no specific grant from any funding agency in the public, commercial, or not-forprofit sectors.

\section{Conflict of Interests}

The authors declare that there are no conflicts of interest related to this article.

\section{References}

Abu Ngozi E, Ezeugwu SC (2008). Risk evaluation of industrial wastewater on plants using onion (Allium cepa L.) chromosome aberration assay. Journal of Tropical Agriculture, Food, Environment and Extension 7(3):242-248.

Adegbite AE, Ayodele MS, Odunbaku KR, Idehen EO (2009). Mutagenic effect of Neem leaf extract used in traditional medicine on Allium cepa (L.). Scientific Research and Essays 4(11):1315-1321. 
Akaneme FI, Iyioke IV (2008). Mutagenic potentials of the sterilizing fluid-Purital on root tip mitosis of Allium cepa. BioResearch 6(1):293-297.

Ali RT, Abdel-Ghany EM, Mohamed FI, Hanna EM, Elashery ZM (2019). Usage of the cyto-genetics and cytology to identify the action mechanisms of two biofertilizers on Allium cepa meristematic cells. Bulletin of the National Research Centre 43:138.

Asli S, Neumann PM (2010). Rhizosphere humic acid interacts with root cell walls to reduce hydraulic conductivity and plant development. Plant and Soil 336:313-322.

Bonciu E, Roșculete E, Olaru AL, Roșculete CA (2018). Evaluation of the mitodepresive effect, chromosomal aberrations and nuclear abnormalities induced by urea fertilization in the meristematic tissues of Allium cepa L. Caryologia 71:350-356.

Bostan C, Butnariu M, Butu M, Ortan A, Butu A, Rodino S, Parvu C (2013). Allelopathic effect of Festuca rubra on perennial grasses. Romanian Biotechnological Letters 18(2):8190-8196.

Bulgari R, Franzoni G, Ferrante A (2019). Biostimulants application in horticultural crops under abiotic stress conditions. Agronomy 9:306.

Butnariu M (2012). An analysis of Sorghum halepense's behavior in presence of tropane alkaloids from Datura stramonium extracts. Chemistry Central Journal 6:75.

Butnariu M, Caunii A (2013). Design management of functional foods for quality of life improvement. Annals of Agricultural and Environmental Medicine 20(4):736-741.

Cerdán M, Sánchez-Sánchez A, Oliver M, Juárez M, Sánchez-Andreu JJ (2009). Effect of foliar and root applications of aminoacids on iron uptake by tomato plants. Acta Horticulturae 830:481-488.

Cerdan M, Sanchez-Sanchez A, Jorda JD, Juarez M, Sanchez-Andreu J (2013). Effect of commercial amino acids on iron nutrition of tomato plants grown under lime-induced iron deficiency. Journal of Plant Nutrition and Soil Science 176:859-866.

Chen J, Lü S, Zhang Z, Zhao X, Li X, Ning P, Liu M (2018). Environmentally friendly fertilizers: A review of materials used and their effects on the environment. Science of the Total Environment 613:829-839.

Csizinszky AA (1990). Response of two bell peppers (Capsicum annuum L.) cultivars to foliar and soil-applied biostimulants. Soil and Crop Science Society of Florida Proceedings 49:199-203.

du Jardin P (2015). Plant biostimulants: definition, concept, main categories and regulation. Scientia Horticulturae 196:3-14.

Firbas P, Amon T (2014). Chromosome damage studies in the onion plant Allium cepa L. Caryologia 67(1):25-35.

Gajc-Wolska J, Radzanowska J, Lyszkowska M (2009). The influence of grafting and biostimulators on physical and sensorial traits of greenhouse tomato fruit (Lycopersicon esculentum Mill.) in field production. Acta Scientiarum Polonorum Hortorum Cultus 8:37-43.

Georgieva N, Nikolova I, Dimitrov V, Dimitrova D (2016). Economic evaluation of forage pea organic production. Banat's Journal of Biotechnology VII(14):60-67.

Heckman JR (1995). Evaluating phosphorus fertilization and commercial biostimulants for producing cabbage. HortTechnology 5:298-300.

Hossain MM, Jahan I (2015). Azospirillum as biofertilizer and Bangladesh perspective. Banat's Journal of Biotechnology $\mathrm{VI}(11): 69-82$.

Janas KM, Posmyk MM (2013). Melatonin, an underestimated natural substance with great potential for agricultural application. Acta Physiologiae Plantarum 35:3285-3292.

Kaushik PS, Ramya M, Gargi GP (2017). Mitodepressive activity of two common food dyes on Allium cepa L. root meristem. International Journal for Research in Applied Science \& Engineering Technology 5(IX):954-967.

Kara M, Sanda MA, Ates A (1994). Cytogenetic effects of the insecticide Cypermethin on the root meristems of Allium сера L. Turkish Journal of Biology 18:323-331.

Kelting M, Harris JR, Fanelli J, Appleton B, Niemiera A (1997). Humate-based biostimulants do not consistently increased growth of container-grown turkish hazelnut. Journal of Environmental Horticulture 15:197-199.

Khanna N, Sharma S (2013). Allium cepa root chromosomal aberration assay: a review. Indian Journal of Pharmaceutical and Biological Research 1(3):105-119.

Kirn A, Kashif SR, Yaseen M (2010). Using indigenous humic acid from lignite to increase growth and yield of okra (Abelmoschus esculentus L.). Soil \& Environment 29:187-191. 
Leme DM, Marin-Morales MA (2009). Allium cepa test in environmental monitoring: A review on its application. Mutation Research 682(1):71-81.

Liman R, Ciğerci IH, Öztürk NS (2015). Determination of genotoxic effects of Imazethapyr herbicide in Allium cepa root cells by mitotic activity, chromosome aberration, and comet assay. Pesticide Biochemistry and Physiology 118:3842.

Lisiecka J, Knaflewski M, Spizewski T, Fraszczak B, Kaluzewicz A, Krzesinski W (2011). The effect of animal protein hydrolysate on quantity and quality of strawberry daughter plants cv 'Elsanta'. Acta Scientiarum Polonorum Hortorum Cultus 10:31-40.

Liu E, Yan C, Mei X, He W, Bing SH, Ding L ... Fan T (2010). Long-term effect of chemical fertilizer, straw, and manure on soil chemical and biological properties in northwest China. Geoderma 158(3):173-180.

Lyszkowska M, Gajc-Wolska J, Kubi K (2008). The influence of biostimulators on yield and quality of leaf and iceberg lettuce - grown under field conditions. In: Dbrowski ZT (Ed). Biostimulators in modern agriculture. Wie Jutra Press, Warszawa pp 28-34.

Neri D, Lodolini EM, Savini G, Sabbatini P, Bonanomi G, Zucconi F (2002). Foliar application of humic acids on strawberry (cv. Onda). Acta Horticulturae 594:297-302.

Osuna D, Prieto P, Aguilar M (2015). Control of seed germination and plant development by carbon and nitrogen availability. Frontiers in Plant Science 6:1023.

Özkara A, Aky1l D, Eren Y, Erdoğmuş SF (2015). Potential cytotoxic effect of Anilofos by using Allium cepa assay. Cytotechnology 67(5):783-791.

Pandia O, Sărăcin I, Chiriac A, Bozga I, Oancea M, Ticu C (2012). Determination of NPK in some local populations of pepper in order to obtain adequate food compliant with the EU food safety rules. Scientific Papers. Series A. Agronomy 55:369-372.

Pandia O, Sărăcin I, Sărăcin AI (2018). Management of agricultural culture establishment works. Scientific Papers Series Management, Economic Engineering in Agriculture and Rural Development 18(2):315-318.

Prokkola S, Kivijärvi Parikka P (2003). Effects of biological sprays, mulching materials, and irrigation methods on grey mould in organic strawberry production. Acta Horticulturae 626:169-175.

Ricci M, Tilbury L, Daridon B, Sukalac K (2019). General principles to justify plant biostimulant claims. Frontiers in Plant Science 10:494.

Rosculete CA, Bonciu E, Rosculete E, Olaru LA (2019). Determination of the environmental pollution potential of some herbicides by the assessment of cytotoxic and genotoxic effects on Allium cepa. International Journal of Environmental Research and Public Health 16:75.

Ruiz JM, Castilla N, Romero L (2000). Nitrogen metabolism in pepper plants applied with different bioregulators. Journal of Agricultural and Food Chemistry 48:2925-2929.

Samfira I, Butnariu M, Rodino S, Butu M (2013). Structural investigation of mistletoe plants from various hosts exhibiting diverse lignin phenotypes. Digest Journal of Nanomaterials and Biostructures 8(4):1679-1686.

Saporta R, Bou C, Frías V, Mulet JM (2019). A method for a fast evaluation of the biostimulant potential of different natural extracts for promoting growth or tolerance against abiotic stress. Agronomy 9:143.

Sharma S, Vig AP (2012). Genotoxicity of atrazine, avenoxan, diuron and quizalofop-P-ethyl herbicides using the Allium cepa root chromosomal aberration assay. Terrestrial and Aquatic Environmental Toxicology 6(2):90-95.

Szparaga A, Kubo M, Kocira S, Czerwinska E, Pawłowska A, Hara P ... Kwasniewski D (2019). Towards sustainable agriculture-agronomic and economic effects of biostimulant use in common bean cultivation. Sustainability $11: 4575$.

Tarantino A, Lops F, Disciglio G, Lopriore G (2018). Effects of plant biostimulants on fruit set, growth, yield and fruit quality attributes of 'Orange Rubis' apricot (Prunus armeniaca L.) cultivar in two consecutive years. Scientia Horticulturae 239:26-34.

Valiente AC, Salgado YR, Remigio Montero AC, Arnaez GP, Fernandez Esperon N, Mancebo Rodriguez A (...) Ocana Arzuagain R (2013). In vivo genotoxic evaluation of biological and organic pesticides and fertilizers. Science International 1:98-102.

Vasileva V (2015). Root biomass accumulation in vetch (Vicia sativa L.) after treatment with organic fertilizer. Banat's Journal of Biotechnology VI(11):100-105.

Yüzbaşioğlu D, Ünal F, Sancak C, Kasap R (2003). Cytological effects of the herbicide racer "flurochloridone" on Allium cepa. Caryologia 56(1):97-105. 
Zhang L, Yan C, Guo Q, Zhang J, Ruiz-Menjivar J (2018). The impact of agricultural chemical inputs on environment: global evidence from informetrics analysis and visualization. International Journal of Low-Carbon Technologies $13(4): 338-352$.

OPEN ACCESS

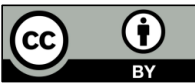

The journal offers free, immediate, and unrestricted access to peer-reviewed research and scholarly work. Users are allowed to read, download, copy, distribute, print, search, or link to the full texts of the articles, or use them for any other lawful purpose, without asking prior permission from the publisher or the author.

License - Articles published in Notulae Botanicae Horti Agrobotanici Cluj-Napoca are Open-Access, distributed under the terms and conditions of the Creative Commons Attribution (CC BY 4.0) License. (C) Articles by the authors; UASVM, Cluj-Napoca, Romania. The journal allows the author(s) to hold the copyright/to retain publishing rights without restriction. 